\title{
Evaluation of Biocontrol Agents against Phytophthora drechsleri F.sp. cajani (Leaf Blight) in Pigeonpea
}

\author{
Sujata Singh Yadav*, Someshwar Bhagat, Vishal Singh, \\ Shahnashi Hashmi and Meghraj Bhagel \\ National Research Centre for Integrated Pest Management, \\ Indian Council of Agricultural Research, India \\ Institute of Agriculture Sciences, Bundelkhand University Campus, Jhansi, India \\ *Corresponding author
}

\section{A B S T R A C T}

\begin{tabular}{|l|}
\hline K e y w o r d s \\
$\begin{array}{l}\text { Phytophthora, } \\
\text { Trichoderama, } \\
\text { Pseudomonas, } \\
\text { antagonist, volatile, } \\
\text { non-volatile } \\
\text { compounds }\end{array}$ \\
\hline Article Info \\
\hline $\begin{array}{l}\text { Accepted: } \\
\text { 26 April } 2020 \\
\text { Available Online: } \\
\text { 10 May } 2020\end{array}$ \\
\hline
\end{tabular}

Pigeon pea is an important pulse crop of the world which is an important source of protein and other nutrients. Phytophthora leaf blight is a major disease of pigeon pea which is caused by Phytophthora drechsleri f.sp. cajani. In vitro evaluation of different isolates of Trichoderma and a strain of Pseudomonas fluorescens against Phytophthora drechsleri f.sp. cajani was carried out to test the efficiency of these antagonists as biocontrol agents against the test pathogen. Ten isolates of Trichoderma spp. and Pseudomonas fluorescens were tested against the blight pathogen under dual culture experiments. Volatile and non-volatile metabolites released from the antagonists were also tested against the pathogen. Percent inhibition in the mycelia growth of the pathogen was determined. All Trichoderma isolates showed significant inhibitory effect on the pathogen in all the experiments. Under dual culture method maximum and minimum percentage of inhibition was showed by AN-33 (81.7\%) and AN-37 (63.4\%) respectively. Under volatile experiments AN-48 $(62.6 \%)$ and $\mathrm{AN}-6(46.9 \%)$ showed maximum and minimum percent inhibition respectively. Under non-volatile experiments, the highest inhibition of pathogen was observed at $15 \%$ concentration of the culture filtrates of the bio agents. At this concentration AN-33 exhibited the maximum $(72 \%)$ and AN-6 showed the minimum (43.5\%) inhibition to the pathogen growth. Pseudomonas fluorescens showed significant inhibition in the mycelial growth of the pathogen under dual culture test with percentage inhibition of $43.02 \%$. The study suggests that the Trichoderma spp. has a potential to be used as biocontrol agents against Phytophthora blight of pigeon pea. Trichoderma isolate AN-33 was identified as the most effective isolate out of the ten isolates studied.

\section{Introduction}

Blight (Phytophthora drechsleri f. sp. cajani) is among the most destructive and widespread disease of Pigeonpea (Cajanus cajan L.) Millsp 1994). The Pathogen damage the pith (the water transport system of the plant) resulting water soaked spots, stem become brown to dark brown, stunting and finally plant die. Phytophthora blight (PB) is caused by Phytophthora drechsleri Tucker f. sp. cajani which was first isolated from wilted pigeonpea plants with stem canker symptoms at the research farm of the Indian Agricultural Research Institute, New Delhi, India and identified by (Williams et al., 1966; Pal et al., 
1970). The disease can be managed in many ways. For effective control, growers use a combination of crop rotation, cultivar resistance and fungicides application. Fungicides such as metalaxyl reported the poor efficacy of applied as seed dressing in protecting older pigeonpea plants against $\mathrm{PB}$. Furthermore, the use of fungicides, besides being expensive and involving risks to the environment associated with the application of chemicals, is not totally effective and may lead to the appearance of new, resistant strains of pathogens (Bruin and Edgington, 1980).

It is therefore necessary to develop alternative ways of control. One such alternative is biological control, in which microorganisms are selected for their ability to antagonise pathogens. Trichoderma controls Ascomycetous, Deutermycetous and Basidiomycetous fungi, which are mainly soil-borne but also air borne pathogen (Chet and Hadar, 1997). T. viride and Gliocladium virens have been effective in the control of Phytophthora spp. causing cotton root disease (Heller and Hedtrich, 1994). G. virens and Trichoderma sp. have been used to control Fusarium oxysporum and Fusarium solani (Zhang et al., 1996) and Rhizoctonia solani (Askew and Laing, 1994).

However, little attention has been paid to their ability to control Phytophthora spp. Trichoderma has several biocide mechanisms; some of them are myco-parasitism (drilling the plant pathogen hyphae wall by production of enzymes like glucanases and chitinase), strangulation of phytopathogen mycelium, competition for space and nutrients and production of secondary metabolites like glyotoxins, viridine, trichodermine, furanone and 6-pentyl-pyrone. Literature reports mycoparasitic fungi displaying lethal mechanisms against phytopathogenic fungi that could be of importance for plant disease biological control (Bélanger et al., 1995; Benhamou and Chet, 1996). Excellent results of integrated control have been attained with strain of Trichoderma and Metalaxyl against Pythium ultimum infecting cotton (Chet and Hadar,1997). Weindling (1932) reported that the potential of Trichoderma species as biocontrol agent of plant diseases was first recognized in early 1930s. The present experiment was undertaken to evaluate the efficacy of the mycelial growth inhibition of $P$. drechsleri f.sp. cajani by Trichoderma isolates, Pseudomonas fluorescens and investigating the mechanisms involved in inhibition under microscopic observation that could be used in the future for $P$. drechsleri f.sp. cajani control.

\section{Materials and Methods}

Collection, identification and purification of test pathogen and antagonists

\section{Isolation of Trichoderma isolate}

The isolates of antagonistic (Trichoderma isolates, Pseudomonas fluorescens) were collected from the Microbial biocontrol lab of National Centre for Integrated Pest Management (NCIPM), New Delhi.

\section{Isolation of Phytophthora}

P. dreschlera Tucker f.sp. cajani (Pal et al., 1970) were identified by distinctive characters mentioned based on the shape and size of, oogonium and oospore formation, temperature requirement and pathogenicity tests. The use of forma specialis was considered appropriate according to the International Rules of Botanical Nomenclature (Stafleu and Bonner, 1972). Then sub culturing, purification and multiplication of the above fungi following hyphal tip technique (Tuite, 1969) were carried out on combined PDA and OMA (1:1) media. 
Antagonist activity of Trichoderma isolates against the P.dreschlera f.sp. cajani

In this study, the reduction in growth and inhibition zone in the dual culture technique was used as the criteria to evaluate the in vitro antagonistic property of ten isolates of Trichoderma isolate (AN12, AN16, AN37, AN38,AN18, AN6, AN44, AN7, AN48, AN48, AN33) (Francisco et al., 2011). All antagonist pathogen combinations were examined on PDA agar in $10 \mathrm{~cm}$ Petri dishes. For dual cultures, mycelial discs (5 mm dia), taken from actively growing, 5-day-old cultures of Phytophthora and Trichoderma isolates, were placed at an extreme of a perti dish. The mix culture was incubated at $25 \pm 1^{\circ} \mathrm{C}$ temperature. Control i.e., without placing the disc of the antagonist only pathogen was kept for comparison. Radial mycelial growth was measured when pathogen's mycelial growth covered whole $9 \mathrm{~cm}$ petri plates. Observations were taken after two, four and seven days of the inoculation date. The following formula was used for calculation the percentage reduction in growth (Moayedi and Ghalamfarsa, 2011), which is,: $(\mathrm{R} 1-\mathrm{R} 2) / \mathrm{R} 1 \times 100$, where $\mathrm{R} 1$ and $\mathrm{R} 2$ were the mycelial radial growth of the pathogen in the control and in the presence of the antagonist, respectively.

\section{Antagonist activity of Pseudomonas fluorescens against the P.dreschlera f.sp. cajani}

To test their antagonist activity of Pseudomonas fluorescens by the dual culture method. P. fluorescens was streaked at the centre in the petri plate. A $5 \mathrm{~mm}$ mycelia disc from the old culture of pathogen was placed on the opposite side in the petri plate. Then these plates were incubated at $28 \pm 2{ }^{\circ} \mathrm{C}$ for 4 days. The growth of pathogen in the test and controlled were observed until the control covered the $80 \%$ of the petri plate.

\section{Effect of Trichoderma volatile substances on $P$. dreschlera f.sp. cajani}

To determine the effects of volatile metabolites, petri dish with PDA was inoculated in the centre with a $5 \mathrm{~mm}$ diameter disc taken from pathogen and antagonist (mycelia disc taken from three days old culture) respectively. Phytophthora petri dish were inverted, placed above the Trichoderma dish and sealed with parafilm (Ting et al., 2010). These Petri dishes were incubated at $25^{\circ} \mathrm{C}$. Growth of the pathogen was recorded by measuring the radius after 3 days. Three replicates were prepared for each strain and plates inoculated only with the pathogen were used as control. Colony diameter of the pathogen was measured at 2, 4 and 6 days after inoculation and the inhibition of mycelial growth determined

\section{Effect of Trichoderma non-volatile antibiotics on $P$. dreschlera f.sp. cajani}

The procedure was as in (Perveen and Bokhari, 2012) with modifications. Two mycelial discs (5 $\mathrm{mm}$ diam), taken from actively growing, 5-day-old cultures of each Trichoderma isolate were placed into $100 \mathrm{ml}$ PDB broth and incubated at $25^{\circ} \mathrm{C}$ for 7 days. The cultures were filtered through sterile Whatman filter no 1 paper and then through $0.2 \mu \mathrm{m}$ millipore filters in order to obtain a sterile liquid from each Trichoderma isolate.

The required volume of culture filtrate was added with known volume of melted PDA to obtain final concentration of 5\%, $10 \%$ and $15 \%(\mathrm{v} / \mathrm{v})$ culture filtrate. The amended media was poured into petri dish. After the agar had solidified, mycelial discs of Phytophthora dreschlera f.sp. cajani (6 $\mathrm{mm}$ diameter), obtained from actively growing colonies were placed in the centre of the agar plates. The Petri dishes were incubated at $28 \pm 1^{\circ} \mathrm{C}$ for 4 days until the control treatment covered the 
petri dish .The PDA medium without addition of culture filtrate of antagonist was served as control. After this time, the percentage of $P$. dreschlera f.sp. cajani inhibition was determined. The radial mycelial growth of test pathogen was measured and per cent inhibition of mycelial growth of pathogen was calculated as mentioned earlier.

\section{Statistical analysis}

All experiments were performed in triplicate, and all statistical analyses were performed using SAS version 8.0 software. Differences in mean values were considered significant when $P<0.05$.

\section{Results and Discussion}

Antagonist activity of trichoderma isolates against the $P$.dreschlera f.sp. cajani

Differential action of the biocontrol agents was noticed on mycelial growth of the $P$. dreschlera f.sp. cajani (Fig. 1a \& Fig. 2a). A reduction in the growth of $P$. dreschlera f.sp. cajani was evidenced when it was paired with antagonists. Among the ten isolates of Trichoderma maximum percentage of inhibition (81.7\%) was recorded with AN-33 isolate followed by $\mathrm{AN}-12(75.6 \%)$, AN38(74.7\%), AN-44(68.6\%), AN-18(68.6\%), $\mathrm{AN}-48(66.0 \%)$, AN-16-(64.3\%) and AN$37(63.4 \%)$, whereas the isolate AN-6 (60.8\%) was recorded with least effective in parasitization of mycelial growth of pathogen.

In the present study was also concluded that $P$. fluorescens maximum inhibition of mycelia growth of pathogen was $43.02 \%$. The result showed that antagonist effect of the antibiotic, chitinase of Pseudomonas fluorescens which helps to degrade the fungal cell wall and inhibit the fungus growth under in vitro condition.
Effect of volatile metabolites of trichoderma spp. on mycelia growth of $\boldsymbol{P}$. drechsleri f.sp cajani

The inhibition of $P$. drechsleri f.sp cajani mycelia growth induced by the volatile compounds produced by the Trichoderma isolate ranged between $62.6 \%$ to $46.9 \%$ (Fig.1b \& Fig. 2b). The major effect was observed with the Trichoderma isolate AN48 and the least with Trichoderma isolate AN-6. It was observed that the ten Trichoderma isolate were able to produce volatile compounds with inhibitory properties against $P$. drechsleri f.sp cajani.

\section{Effect of tichoderma isolate non-volatile} substances against $\boldsymbol{P}$. drechsleri f.sp. cajani

The results of effect of non-volatile compounds revealed that among the different isolates of Trichoderma evaluated against Phytophthora (Fig.1c \& Fig.2c). In general, maximum inhibition $(69.40 \%)$ of the mycelial growth of Phytophthora was observed with the culture filtrate of Trichoderma isolate, $\mathrm{AN}-33$ at $15 \%$ concentration. AN-38 (69.40), isolate of Trichoderma isolate caused maximum growth inhibition followed by isolate of $\mathrm{AN}-12$ (65.9\%), AN-44 (62.3\%) AN-48 (59.2\%), AN-18(58.0\%), AN-16 (56.9\%), AN-7 (53.7\%), AN-37 (49.0\%) and least percentage inhibition was observed with the isolate AN-6 by $43.5 \%$. with statistically at par result.

Phytophthora is one of the yield limiting factors of pigeonpea across the country. The advantage of the use of biocontrol includes environmental safety, cost effective. In this studied it found the Trichoderma isolates and Pseudomonas fluorescens showed the higher percentage of inhibition against $P$. dreschlera f.sp. cajani. 

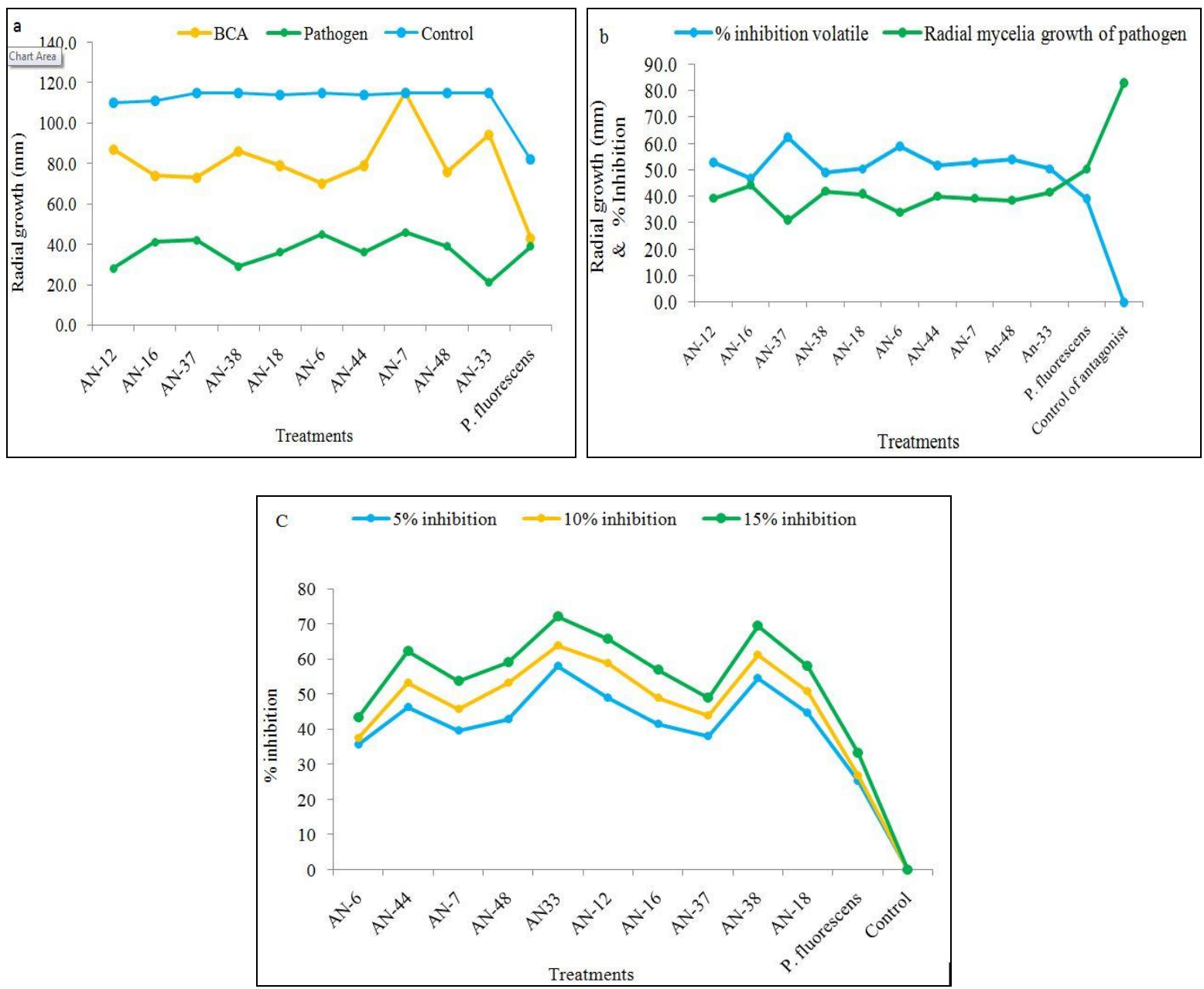

Fig.1 Growth pattern of P.dreschlera f.sp. cajani and the biological control agents (BCA) in terms of radius of the colony (a) Interaction of biocontrol agents against pathogen - Dual culture method (b) Volatile activity of biocontrol agents against pathogen (c) Non- volatile activity of biocontrol agents against pathogen. All the data is significant $P$ value $(P \leq 0.05)$
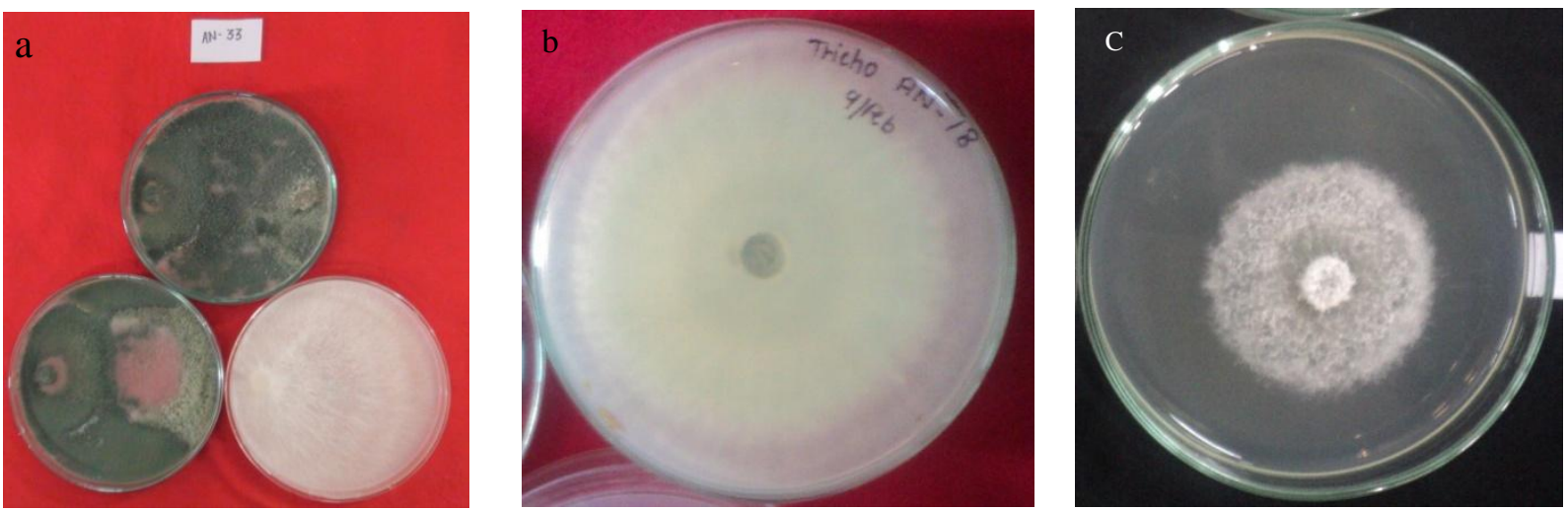

Fig.2 Morphology of antagonism produced by BCA. (a) Antagonist activity due to dual culture technique (b) Effect of volatile metabolites concentration)

(c) Non-volatile substance produces $(15 \%$ 
The inhibition percentages of these isolates are differing from each other due to their antagonist activity by differential secretion of antifungal substance. The highest growth is showed by Trichoderma isolate AN 33 in dual culture due to direct contact of mycelia hyphae lysed and $P$. fluorescens was also effective as an antagonist against P.dreschlera f.sp. cajani under dual culture test (Paul and Sarma, 2005) studied. The antagonistic effects of metabolites of $P$. fluorescens strain on the different growth phases of Phytophthora capsici, foot rot pathogen of black pepper ( Barnett and Binder, 1973) and (Elad et al., 1983) who observed inhibitions is and parasitism by Trichoderma spp. of some species of Phytophthora. dreschlera f.sp. cajani. But in volatile or non-volatile these isolates produces various toxic and antibiotics metabolites (Claydon et al., 1987; Dennis and Webster, 1971a \& b; Lorito, 1994) and enzymes (Lorito, 1993) which are involved in the inhibition and lysis of pathogenic fungi.

In this studied showed that Trichoderma isolate $\mathrm{AN}-48$ produced highly volatile metabolites that were inhibitory effect on $P$. dreschlera f.sp. cajani. Non-volatile metabolites also produced by AN-33 of our Trichoderma isolates inhibited the growth of the plant pathogens tested. In vitro and in vivo studies of the behavior of Phytophthora spp. in the presence of antagonistic fungi such as T. harzianum, Gliocladium spp. (Smith et al., 1990) or Pythium nunn and Penicillium funiculosum (Fang and Tsao., 1995) have shown the biocontrol capacity of these fungi on Phytophthora spp.

To test the in vitro screening showed that bioantagonists effective against soil borne pathogens is a simplistic and economic approach to control the diseases. Hence, work is needed towards a better understanding and development of technology that allow the biocontrol agent to spread and proliferate in soil. However, (Papavizas, 1985) research indicated the improvement of strains of biological agents that are more capable of becoming established and surviving under adverse field conditions. Thus, it is obvious that biological control offers, durable environmentally safe and cost effective alternative to chemical for the efficient management of plant disease.

The present studies exhibit ten isolates of Trichoderma and Pseudomonas fluorescens are produce antifungal metabolites against the $P$. dreschlera f.sp. cajani. This showed a real alternative to chemical application. This research focused on the antagonistic property of ten isolates of Trichoderma and $P$. fluorescens against $P$. dreschlera f.sp. cajani. All the isolates of the fungal antagonist caused significant reduction in the mycelium growth of pathogen in vitro, in all the three experiment. In the dual culture experiment, Trichoderma islolate AN-33 exhibited the maximum percent inhibition (81.7) to the mycelia growth of pathogen. The effectiveness of $P$. fluorescnes on $P$. dreschlera f.sp. cajani. was evaluated by conducting dual culture test and reduced the mycelia growth of the pathogen. This has resulted in a good understanding to direct contact of bioagents with the pathogen and effect of metabolites in suppression of the pathogen. These biocontrol are not only beneficial for controlling a disease but also it enhances the plant growth. Biocontrol is very effective management for disease management. The antimicrobial activity of Trichoderma and $P$. fluorescens are very effective for controlling the disease.

\section{Acknowledgment}

This research facilities provided by National Centre for Integrated Pest Management, ICAR, New Delhi, India. 


\section{References}

Askew, D. J., \& Laing, M. D. (1994). The in vitro screening of 118 Trichoderma isolates for antagonism to Rhizoctonia solani and an evaluation of different environmental sites of Trichoderma as sources of aggressive strains. Plant and Soil, 159(2), 277-281.

Barnett, H.L., \& F.L. Binder (1973). The fungal host-parasite relationship. Annual Review of Phytopathology II, 273-292.

Bélanger, R. R., Dufour, N., Caron, J., \& Benhamou, N. (1995). Chronological events associated with the antagonistic properties of Trichoderma harzianum against Botrytis cinerea: indirect evidence for sequential role of antibiosis and parasitism. Biocontrol Science and Technology, 5(1), 41-54.

Benhamou, N., \& Chet, I. (1996). Parasitism of sclerotia of Sclerotium rolfsii by Trichoderma harzianum: ultrastructural and cytochemical aspects of the interaction. Phytopathology, 86(4), 405416.

Bruin, G. C., \& Edgington, L. V. (1980, January). Induced resistance to ridomil of some oomycetes. In Phytopathology (Vol. 70, No. 5, pp. 459-460). 3340 Pilot Knob Road, St Paul, Mn 55121: Amer Phytopathological Soc.

Chet, I., Inbar, J. and Hadar, I. (1997). Fungal antagonists and mycoparasites. In The Mycota IV: Environmental and microbial relationships. ed. D.T. Wicklow, B. Söderström. 165-184. Springer-Verlag, Berlin.

Claydon, N., Allan, M., Hanson, J. R., \& Avent, A. G. (1987). Antifungal alkyl pyrones of Trichoderma harzianum. Transactions of the British Mycological Society, 88(4), 503-513.

Dennis, C., \& Webster, J. (1971).
Antagonistic properties of speciesgroups of Trichoderma: I. Production of non-volatile antibiotics. Transactions of the British Mycological Society, 57(1), 25-IN3.

Dennis, C., \& Webster, J. (1971). Antagonistic properties of speciesgroups of Trichoderma: II. Production of volatile antibiotics. Transactions of the British Mycological Society, 57(1), 41-IN4.

Elad, Y., Chet, I., Boyle, P., \& Henis, Y. (1983). Parasitism of Trichoderma spp. on Rhizoctonia solani and Sclerotium rolfsii-scanning electron microscopy and fluorescence microscopy. Phytopathology, 73(1), 85-88.

Fang, J. G., \& Tsao, P. H. (1995). Evaluation of Pythium nunn as a potential biocontrol agent against Phytophthora root rots of azalea and sweet orange. Phytopathology, 85(1), 29-36.

Heller, W. E., \& Theiler- Hedtrich, R. (1994). Antagonism of Chaetomium globosum, Gliocladium virens and Trichoderma viride to four soil- borne Phytophthora species. Journal phytopathology, 141(4), 390-394.

Hernandez, C., Berlanga, P., Gallegos, M., Cepeda, S., Rodriguez, H., Aguilar, G., \& Castillo, R. (2011). In vitro antagonist action of Trichoderma strains against Sclerotinia sclerotiorum and Sclerotium cepivorum. American Journal of Agricultural and Biological Sciences, 6(3), 410-417.

Lorito, M., Hayes, C. K., Di Pietro, A., Woo, S. L., \& Harman, G. E. (1994). Purification, characterization, and synergistic activity of a glucan 1, 3beta-glucosidase and an N-acetyl-betaglucosaminidase from Trichoderma harzianum. Phytopathology (USA).

Lorito, M., Hayes, C. K., Di Pietro, A., Woo, S. L., \& Harman, G. E. (1994). Purification, characterization, and 
synergistic activity of a glucan 1, 3beta-glucosidase and an N-acetyl-betaglucosaminidase from Trichoderma harzianum. Phytopathology (USA).

Monte, E. (2001). Understanding Trichoderma: between biotechnology and microbial ecology. International Microbiology, 4(1), 1-4.

Pal, M., Grewal, J. S., \& Sarbhoy, A. K. (1970). new stem rot of arhar caused by Phytophthora. Indian Phytopathology.

Papavizas, G. C. (1985). Trichoderma and Gliocladium: biology, ecology, and potential for biocontrol. Annual review of phytopathology, 23(1), 23-54.

Paul, D., \& Sarma, Y. R. (2006). Antagonistic effects of metabolites of Pseudomonas fluorescens strains on the different growth phases of Phytophthora capsici, foot rot pathogen of black pepper (Piper nigrum L.). Archives of Phytopathology and Plant Protection, 39(02), 113-118.

Perveen, K., \& Bokhari, N. A. (2012). Antagonistic activity of Trichoderma harzianum and Trichoderma viride isolated from soil of date palm field against Fusarium oxysporum. African Journal of Microbiology Research, 6(13), 3348-3353.

Smith, V. L., Wilcox, W. F., \& Harman, G. E. (1990). Potential for biological control of Phytophthora root and crown rots of apple by Trichoderma and Gliocladium spp. Phytopathology, 80(9), 880-885.

Stafleu, F. A., and C. E. Bonner. "International Code of Botanical Nomenclature adopted by the Xvth International Botanical Congress, Seattle, August 1969." International. Association Plant Taxonomy, Utrecht (1972): 426.

Ting, A. S. Y., Mah, S. W., \& Tee, C. S. (2010). Identification of volatile metabolites from fungal endophytes with biocontrol potential towards Fusarium oxysporum F. sp. cubense Race 4. American Journal of Agricultural and Biological Sciences, 5(2), 177-182.

Tuite, J. (1969). Plant pathological methods. Fungi and bacteria. Plant pathological methods. Fungi and bacteria.

Weindling, R. (1932). Trichoderma lignorum as a parasite of other soil fungi. Phytopathology, 22(8), 837-845.

Zhang, J., Howell, C. R., \& Starr, J. L. (1996). Suppression of Fusarium colonization of cotton roots and Fusarium wilt by seed treatments with Gliocladium virens and Bacillus subtilis. Biocontrol Science and Technology, 6(2), 175-188.

\section{How to cite this article:}

Sujata Singh Yadav, Someshwar Bhagat, Vishal Singh, Shahnashi Hashmi and Meghraj Bhagel. 2020. Evaluation of Biocontrol Agents against Phytophthora drechsleri F.sp. cajani (Leaf Blight) in Pigeonpea. Int.J.Curr.Microbiol.App.Sci. 9(05): 3536-3543.

doi: https://doi.org/10.20546/ijcmas.2020.905.421 